\title{
Effects of Emerald Ash Borer Infestation on the Structure and Material Properties of Ash Trees
}

\author{
Anand B. Persad, John Siefer, Roy Montan, Scott Kirby, Oscar J. Rocha, Michael E. Redding, \\ Christopher M. Ranger, and Andrew W. Jones
}

\begin{abstract}
Emerald ash borer (EAB), an invasive insect borer on ash trees, currently occurs in the Untied States and Canada. In many regions, large populations of ash trees are affected with many trees exhibiting partial to full canopy dieback. Several cases exist in northwest Ohio, U.S., where EAB infested ash branches or stems fail prematurely during deadwood pruning or whole tree removal. This study was initiated to resolve the effects of EAB on the material properties of ash branches and stems. Visually non-infested ash trees and trees with recent and advanced EAB activity were examined. The data from static loading tests on primary branches indicate that maximum bending stress at failure was not significantly lower in EAB infested trees compared to non-infested trees. Examination of the fracture zone, however, revealed that wood moisture was significantly lower and more cracking was observed in wood sections of branches taken from EAB infested trees. During static loading, branch failure at the union occurred only in the EAB infested trees. In a wood resistance evaluation of infested and non-infested ash stems, significantly lower resistance was observed in advanced EAB infested ash stems when drilled at the base compared to drill sites $1 \mathrm{~m}$ above. This was not observed at similar drill site heights in the visually non-infested ash stems. These data may help identify risk elements associated with structural and material degradation of ash wood as early as one to two years after infestation by EAB.

Key Words. Anchor Points; Biomechanics; Branch Failure; Emerald Ash Borer; Resistance Drilling; Static Loading; Zone of Fracture.
\end{abstract}

Emerald ash borer (EAB) (Agrilus planipennis Fairmaire), was identified in mainland North America in 2002 in Michigan and Ontario (Haack et al. 2002). Invasive borers such as EAB may not be suppressed by natural forces upon introduction into new territory and often exploit resources beyond the carrying capacity. Currently EAB has been recorded in 15 states in the United States, as well as in Ontario and Quebec in Canada. The Ohio Department of Natural Resources estimates that 3.8 billion ash trees with standing timber valued at more than USD \$1 billion could be affected in Ohio. EAB also has been deemed to have the potential to virtually eliminate ash as a component of the North American forests, affecting ecosystem processes and plant and animal communities (Herms et al. 2004).

In a study of ice storm damage in urban trees in Champaign, Illinois, U.S., Hauer et al. (1993) reported that $6.9 \%$ of 290 green ash trees suffered the highest severity ratings and ranked green ash seventh (category: susceptible) in decreasing order of damage severity out of 25 urban tree species. Green ash is often considered as an intermediate landscape tree in terms of susceptibility to breakage; increased risks of ash tree failure associated with EAB infestation have become a cause for concern, especially as it pertains to tree worker safety in EAB infested areas. In spring 2009, an unusual number of EAB ash tree work-related incidents (Scott Kirby, pers. comm.) occurred in the greater Toledo, Ohio, area. Most of the incidents involved do-it-yourself homeowners; at least one case involved a professional arborist.

Static loading of primary branches (Study Part 1) and resistance drill measurements (Study Part 2) of stems of green ash trees com- prised the major techniques used to examine the effects of EAB on the material properties of ash trees. Trees were sourced in the greater Toledo area, a region of Ohio where large tracts of ash trees were infested by EAB for several years. Visually un-infested ash trees and trees under infestation for varying duration were evaluated.

\section{MATERIALS AND METHODS}

The effects of EAB on the structure and material properties of branches and stems of green ash (Fraxinus pennsylvanica Marsh) were evaluated in this study using two standard tests:

- Study Part 1: Static loading of branches.

- Study Part 2: Resistance drill assessments of lower portions of the stem.

\section{Tree and Branch Selection}

Green ash trees with trunk diameter at breast height (DBH) ranging from 30 to $50 \mathrm{~cm}$ were selected in recreation park environments in and around the city of Perrysburg in northwest Ohio. All selected trees were 12 - to 15 -years-old, 10 to $14 \mathrm{~m}$ in height and measured 5 to $7 \mathrm{~m}$ in drip line diameter. Three groups of five trees each were selected based on age of EAB infestation, further described as:

- Group I: Five ash trees that showed no visible signs of EAB infestation.

- Group II: Five ash trees that were currently infested with EAB (within the last two years) and had at least two thirds of their canopies still intact. 
- Group III: Five ash trees that after confirmed EAB infestation had dead canopies (there were no signs of life in terminal branches). All trees had small amounts of epicormic sprouting at the base. Based on the city forester's records, it is estimated that initial EAB infestation may have been three to four years earlier.

The ultimate fracture force, moments, and bending stresses at the point of fracture were determined by applying static loads to an approximate center of gravity (visually estimated) of selected branches. Three branches from each of five ash trees in each group were loaded until failure. Forty-five branches were thus broken in this study. Pre branch-breaking measurements that were recorded included: DBH using an arborist diameter tape and branch diameter at the branch collar using a hinged caliper (12.5 $\mathrm{cm}$ ) (Forestry Supplies, California, U.S.). Visual estimates (based on initial measurements of first few branches) of the approximate angle of the branch attachment (branch to stem attachment angles ranged from 10 to 60 degrees upward slope) were also recorded. Only first order branches that were directly attached to the main trunk were selected. Branches were between 3 to $10 \mathrm{~cm}$ in diameter and any with apparent defects were not used in the trial.

\section{Study Part 1. Static Loading of Branches}

A $2,925 \mathrm{~kg}, 1.27 \mathrm{~cm}$, three-strand rope (New England Ropes) was tied around the base of the target tree using a clove hitch knot [Rope A] (Figure 1). A 1,000 kg hand winch or 'come along' (Lug All Corporation, Morgan, Pennsylvania, U.S.) [C] was connected to rope A using a $3,960 \mathrm{~kg}, 8 \mathrm{~mm}$ spliced loop (Sherrill Tree, Greensboro, North Carolina) [D] and a six-coil Prusik knot. The hook in the come along could then go through the loop made in the spliced loop. Rope A was connected to the rear mounted hitch of a stationary truck (Ford F-150) and pulled taut using the come along. Rope A formed a firm horizontal anchor line to

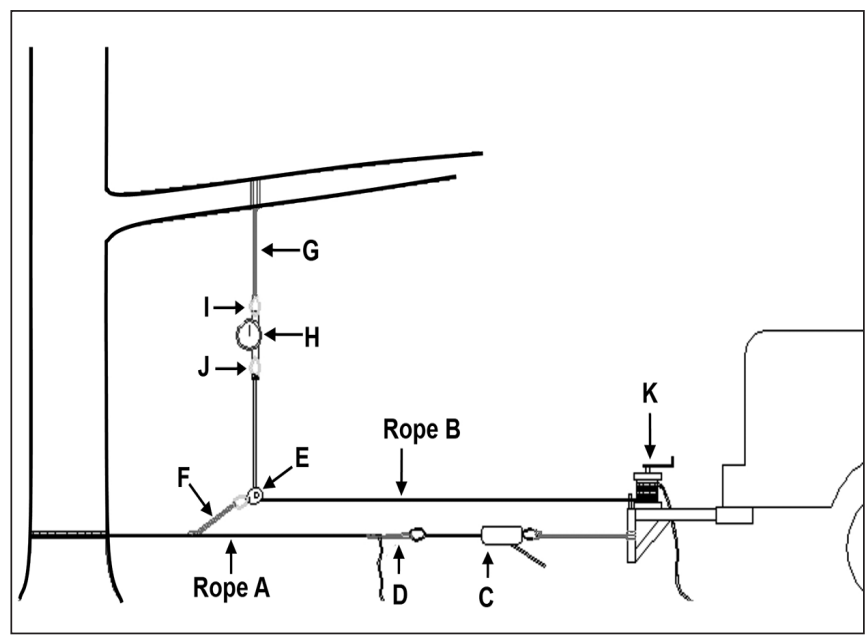

Figure 1. Schematic outline of the ropes and equipment configuration used for static loading branches from visually un-infested and EAB-infested green ash trees in an evaluation of the material properties of ash trees in northwest Ohio in 2009. (A) Horizontal anchor rope, (B) tension rope, (C) hand winch, (D) six-coil Prusik knot, (E) rigging pulley, (F) blue streaked splice loop, (G) polyester strap, (H) dynamometer, (I and J) double locking carabiner, (K) Good Rigging Control System. which a $3,825 \mathrm{~kg}, 7.62 \mathrm{~cm}$ rigging pulley (CMI, Franklin, West Virginia, U.S.) [E] was connected, using a $3,645 \mathrm{~kg}, 1.27 \mathrm{~cm}$ blue streak spliced loop (Samson Ferndale, Washington, U.S.) [F].

A second rope system [Rope B] consisted of a 4,005 kg yellow endless polyester strap (Buckingham) [G] that was looped using a girth hitch around the target branch at an estimated (visually) approximate center of gravity (CGv). A Dillon $500 \mathrm{~kg}$ dynamometer (Dillon Quality Plus Inc., Kansas City, Missouri, U.S.) $[\mathrm{H}]$ was connected using a $5,058 \mathrm{~kg}$ steel rigging double locking carabiner (International Safety Components, Ltd, Bangor, Gwynedd, UK) [I]. At the bottom of the dynamometer, another rigging double locking carabiner $[\mathrm{J}]$ was connected to a three-strand rope $(3,200 \mathrm{~kg})$ with an anchor bend. The rope was then threaded through the $7.6 \mathrm{~cm}$ rigging pulley [E] that was attached to Rope A. Rope B was then wound around the $900 \mathrm{~kg}$ capacity Good Rigging Control System (GRCS, Greg Good, Wisconsin, U.S.) [K] and mounted on a platform connected to a standard trailer hitch on the rear of the truck. The GRCS was used to apply the static load.

Upon limb breakage, an arborist climber used a hand saw to prune off the entire broken limb at the point of union with the trunk. The branch was then lowered to the ground. Six main post branch-breaking measurements that offered meaningful relationships in the study were retained for further calculations:

(1) Ultimate fracture force $(F)$ determined from the dynamometer at time of breakage

(2) Entire length of the broken branch $\left(\mathrm{L}_{\mathrm{B}}\right)$ measured along the branch

(3) Distance ( $L=$ lever arm) between the projection (vertical to a horizontal plane) of the load application point and the projection (vertical to a horizontal plane) of the fracture point along a horizontal line (Lilly and Sydnor 1995)

(4) Diameter (D) of the branch as close to the fracture as possible and on the branch and stem-union side. Two measurements on opposite orientations were taken and a mean value was computed.

(5) Distance of fracture point from branch union $\left(\mathrm{L}_{\mathrm{FU}}\right)$ along the branch

(6) $\mathrm{L}_{\mathrm{FU}}$ as a percentage of the entire branch length $\mathrm{L}_{\mathrm{B}}\left(\% \mathrm{~L}_{\mathrm{FU}} \mathrm{L}_{\mathrm{B}}\right)$

\section{Calculation of Moments and Bending Stresses}

The moment $(\mathrm{M})$ and maximum bending stress $(\sigma)$ at failure were calculated according to Lilly and Sydnor (1995). Moments (M) were calculated using the formula: $\mathrm{M}=\mathrm{F} \cdot \mathrm{L}$; maximum bending stress $(\sigma)$ at failure was calculated using the formula: $\sigma=4 \mathrm{FL} / \pi \mathrm{r}^{3}$. Radius (r) used was determined from diameter (D).

\section{The Zone of Fracture}

A region of the branch consisting of the visually identified fracture (usually within approximately $30 \mathrm{~cm}$ on either side of the break zone) was sawed off, photographed, and labeled. This region was considered the zone of fracture (ZF) in the study. Visual checks were made on all failed branches to ensure that no areas of decay or cankers that could potentially compromise the evaluations were present. Branch cross section discs measuring $2.54 \mathrm{~cm}$ thick were cut 48 hours after severing the ZF from trees using a $25.4 \mathrm{~cm}$ compound miter saw. Discs were taken as close to the fracture point as possible and towards the branch collar. Discs were weighed to 
the nearest $0.1 \mathrm{~g}$ to obtain green weights $(\mathrm{Gw})$. The discs were dried in an oven at $104^{\circ} \mathrm{C}$ for 24 hours and reweighed to obtain dry weights $(\mathrm{Dw})$. The oven dry volume $\left(\mathrm{V}_{\mathrm{D}}\right)$ of each disc was determined by first dipping the entire $2.54 \mathrm{~cm}$ wood sections in molten paraffin wax and allowed to drip dry to ensure only a thin wax seal remained (the ratio of the volume of wax to that of the wood was considered negligible and is one limitation of this protocol). The wood discs were then totally submerged in a graduated $\left(\mathrm{cm}^{3}\right)$ container of water the volume of the displaced water represents the oven dry volume $\left(\mathrm{V}_{\mathrm{D}} \mathrm{cm}^{3}\right)$ of the wood disc.

Two evaluations were carried out as per standard wood measurement protocol (USDA; Forest Products Laboratory 1987; also Farrell 2003) on disc samples extracted within the ZF:

(i) Percent moisture $\left(\mathrm{P}_{\text {moist }}\right)=[(\mathrm{Gw}-\mathrm{Dw}) / \mathrm{Dw}] \times 100$

(ii) Spec. Grav. (oven dry basis) $\left(\mathrm{SG}_{\mathrm{Dw}}\right)=$ [oven dry weight $\mathrm{D}_{\mathrm{w}}$ (g) $\left./ \mathrm{VD}\left(\mathrm{cm}^{3}\right)\right] / 1 \mathrm{~g} / \mathrm{cm}^{3}$ (density of water)

\section{Total Linear Cracks}

Cracks present on the surface of the cross section of the wood disc samples that faced the fracture point were measured after first dusting with talc powder and shaking excess powder off. Visible cracks were then measured using a divider and added cumulatively to produce a total linear value (cm) (TLC).

\section{Statistical Analysis}

Moments and bending stresses at the fracture point, $\%\left(\mathrm{~L}_{\mathrm{FU}} \mathrm{L}_{\mathrm{B}}\right)$, Moisture content $\mathrm{P}_{\text {moist }}$, specific gravity $\mathrm{SG}_{\mathrm{Dw}}$, and TLC were compared across treatments using ANOVA. Means were separated using the Scheffe Grouping, SAS statistical software (SAS Institute, Cary, North Carolina, U.S.). Percentage data for $\left(\% \mathrm{~L}_{\mathrm{FU}} \mathrm{L}_{\mathrm{B}}\right)$ was square root transformed before analysis.

\section{Study Part 2: Evaluation of the Resistance of Stem Tissue at Two Drill Heights in Two Groups of Ash Trees}

Ash trees ranging in diameter at breast height from $30 \mathrm{~cm}$ to 50 $\mathrm{cm}$ were selected in recreation park environments in and around the city of Perrysburg, Ohio. Two groups were selected for this trial similar to Group I and Group III trees in Part 1 of this study. Each group consisted of five trees. Trees used in Study Part 1 were not used in Study Part 2. An F400-S model (IML, Atlanta, Georgia, U.S.) was used to evaluate the resistance to drilling in the stems of the two ash tree groups. Measurements were taken in two directions (north to south and east to west) at the base and at $1 \mathrm{~m}$ height of stems of all tree replicates. An airspade $(155 \mathrm{cfm})$ was used to excavate around the base to provide clear access if needed. Stem diameter at each drill height was measured using an arborist diameter tape. The height resistance readings (from chart printouts) were read in millimeters at 1.27 $\mathrm{cm}$ increments into the stem (reflected as a percentage of the stem diameter at successive increments). Resistance (mm) values obtained for drill points (NS or EW) at the base or at the $1 \mathrm{~m}$ height for trees in Group I were plotted separately against the corresponding incremental increase in percentage stem diameter. Separate scatterplots were thus obtained for each height (and direction) of drill point for all trees in Group I. This was repeated for resistance $(\mathrm{mm})$ values obtained for drill points at the two stem heights of the trees assessed in Group III.

\section{Statistical Analysis}

Regression analyses with height of drill point as an indicator variable were conducted for each group of trees using SAS statistical software.

\section{RESULTS AND DISCUSSION}

\section{Study Part 1}

\section{Moments and Bending Stresses}

Moments and bending stresses calculated at branch fracture were not significantly different $(\mathrm{F}=0.47, \mathrm{DF}=3,38$, $\mathrm{P}=0.70$ and $\mathrm{F}=0.74, \mathrm{DF}=3,38, \mathrm{P}=0.53$, respectively) among the three groups of ash trees tested (Table 1). These data are further discussed within the context $\mathrm{P}_{\text {moist }}$ and TLC.

\section{Comparison of Percentage Distance from Fracture Point to Union to Entire Branch Length $\left(\% \mathrm{~L}_{\mathrm{FU}} \mathrm{L}_{\mathrm{B}}\right)$ Across Groups}

The $\% \mathrm{~L}_{\mathrm{FU}} \mathrm{L}_{\mathrm{B}}$ comparisons from broken branches were significantly $(\mathrm{F}=63.00, \mathrm{DF}=3,18, \mathrm{P}<0.0001)$ different among the groups (Table 1). The mean $\pm \mathrm{SE} \% \mathrm{~L}_{\mathrm{FU}} \mathrm{L}_{\mathrm{B}}$ values were highest in Group I trees and lowest in Group III trees which may suggest a possible shift in fracturing towards the union. Goodfellow (2009) identified a critical zone of failure within twenty percent of the branch length to the union with the main stem. The frequency of branch breakage also peaked in this region in this study (Figure 2). Of the 45 branches broken in total, six fractures or $13.3 \%$ occurred at the point of union with the stem $\left(\mathrm{L}_{\mathrm{FU}}=0\right)$, these branches were all within a range of 3 to $7 \mathrm{~cm}$ in diameter. Interestingly three branches were from Group II trees and three originated from Group III trees.

\section{The Zone of Fracture for $\mathbf{P}_{\text {moist }}, \mathbf{S G}_{\mathrm{DW}}$, and Wood Strength} $\mathrm{P}_{\text {moist }}$ was significantly $(\mathrm{F}=10.80, \mathrm{DF}=3,38, \mathrm{P}<0.001)$ lower in Group III trees compared to $\mathrm{P}_{\text {moist }}$ from sample discs cut from trees in Groups I and II, which were statistically homogenous with each other (Table 1). Despite variable wood moisture content this did not directly affect maximum stress at failure or strength upon static loading. Farell (2003) reported similar findings between variable moisture content with harvest date but found similar strength at breaking was observed in sawtooth oak (Quercus acutissima Carruthers) and red maple (Acer rubrum) crotches. Wood moisture decreases have generally been more aligned with increase in strength of harvested wood in the traditional sense. In the context of living trees, drier wood may not necessarily constitute a stronger tree. Significantly lower wood moisture coupled with rotational forces from wind loading or incidental loading from snow or ice could increase risk of wood failure.

$\mathrm{SG}_{\mathrm{DW}}$ calculated for wood disc samples taken from the $\mathrm{ZF}$ of the three groups of ash trees was not significantly different among groups $(\mathrm{F}=0.73, \mathrm{DF}=3,37, \mathrm{P}=0.54$ ) (Table 1). While specific gravity of wood may be correlated with strength in trees (Zoebel and van Buijtenen 1989; Niklas 1997), other studies, such as Lilly and Sydnor (1995), found that although Norway maple (Acer platanoides L.) had a significantly higher specific gravity than silver maple (Acer saccharinum L.), no significant variation was observed in bending stresses at fracture point between the two maple species. 


\section{Total Linear Cracks}

The TLC $(\mathrm{cm})$ in wood disc samples from the ZF was significantly different among the tree groups $(\mathrm{F}=17.64, \mathrm{DF}=3,38$, $\mathrm{P}<0.0001)$. Wood discs taken from Group III trees had highest total cumulative linear cracking while discs taken from Group I trees had least cracking (Table 1). The linear cracks increased with decrease in moisture $\left(Y=-0.33+20.6 ; r^{2}=0.32\right)$ (Figure 3$)$. Total cracks present may be indicative of the wood integrity in the ZF. While this may not be entirely representative of true branch strength, it underscores the significant variability of ash wood behavior after EAB interaction as early as two years of infestation.

\section{Study Part 2: Evaluation of the Resistance of Stem Tissue at Two Drill Heights in Two Groups of Ash Trees}

The resistance of stem wood tissue at $1 \mathrm{~m}$ above the base was not significantly different $(\mathrm{F}=2.63$, DF $2,453, \mathrm{P}>0.05)$ compared to drill points at the base when measured for trees in Group I (visually un-infested ash trees) (Figure 4). Resistance at drill points observed for trees in Group III (EAB infested trees) was significantly $(\mathrm{F}=44.22$, DF $2,464, \mathrm{P}<0.001)$ higher at $1 \mathrm{~m}$ compared to drill points at the base (Figure 4). These data suggest that the variation in the integrity of the wood at the base of ash tree stems compared to $1 \mathrm{~m}$ above may indicate material degrada- tion with advanced EAB infestation. Material degradation may be indicative of strength loss and may introduce potential risk factors. Further research is needed especially to further evaluate the behavior of EAB infested ash stems to dynamic loads.

\section{SUMMARY}

These data are based on the effects caused by the interaction of EAB with its preferred ash tree host over time. Ellison (2005), in a quantified tree risk assessment study, remarked of environment and biological entities that "precise quantification of potential for tree failure is unlikely to be achievable"; the researchers of the current study could not agree more. The data from this study identify that EAB-infested ash trees are compromised as early as two years after initial infestation and basal decline may occur with advancing infestation. Hauer et al. (1993), in an evaluation of ice storm damage to urban trees, concluded that deadwood present in the crown predisposes trees to further wind damage. Canopies of ash trees after early to intermediate EAB infestation often suffer dieback resulting in substantial deadwood accumulation. James and Kane (2008) cautioned that forces exerted by winds on branches may cause failure not predicted by static loading tests. The authors have found indication that branch failure may sometimes occur closer to the union in EAB infested ash trees under static loading. In addition to wind and ice and snow loading, climbing

Table 1.Mean \pm SE of post branch breaking parameters determined after static loading branches from visually non-infested and EAB infested green ash trees after static loading in an evaluation of the material properties of ash trees in northwest Ohio in 2009.

\begin{tabular}{|c|c|c|c|c|c|c|}
\hline \multirow[b]{2}{*}{ Parameter } & \multicolumn{6}{|c|}{ Mean \pm standard error } \\
\hline & Group I & Group II & Group III & $P$-value & F Value & DF \\
\hline Moments Nm & $959 \pm 142$ & $2423 \pm 459$ & $1546 \pm 441$ & 0.70 & 0.47 & 3,38 \\
\hline Bending stress $\mathrm{N} / \mathrm{mm}^{2}$ & $497 \pm 115$ & $653 \pm 83$ & $650 \pm 106$ & 0.53 & 0.74 & 3,38 \\
\hline$* \% \mathrm{~L}_{\mathrm{L}} \mathrm{L}$ & $5.62 \pm 0.11 \mathrm{~A}$ & $4.42 \pm 0.11 b$ & $3.13 \pm 0.13 \mathrm{C}$ & $<0.0001$ & 63.00 & 3,18 \\
\hline Percent moisture & $59.17 \pm 5.44 \mathrm{~A}$ & $52.90 \pm 5.52 \mathrm{a}$ & $27.68 \pm 5.18 \mathrm{C}$ & $<0.0001$ & 10.80 & 3,38 \\
\hline TLC (cm) & $4.69 \pm 1.15 \mathrm{c}$ & $10.26 \pm 1.18 b$ & $15.72 \pm 1.10 \mathrm{a}$ & $<0.008$ & 17.64 & 3,38 \\
\hline $\mathrm{SG}_{\mathrm{Dw}}$ & $0.59 \pm 0.27 \mathrm{a}$ & $0.48 \pm 0.25 \mathrm{a}$ & $0.70 \pm 0.18 a$ & 0.54 & 0.73 & 3,37 \\
\hline
\end{tabular}

Notes: Asterisk (*) indicates untransformed means represented. Significant variation among groups is indicated by different letters in a row; ANOVA means separated by Scheffe's grouping at $5 \%$ level.

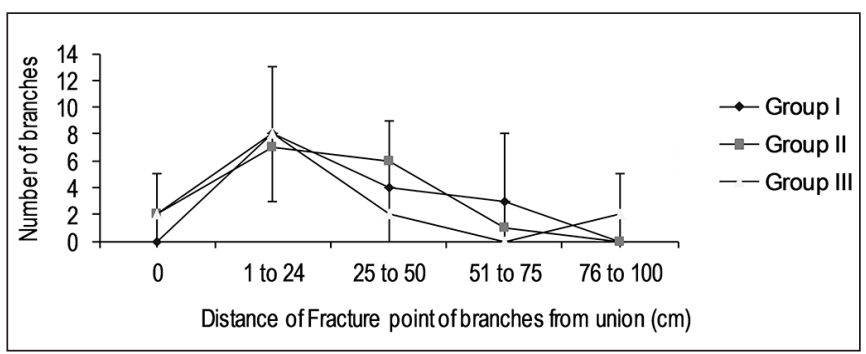

Figure2. Frequency of breakage based on distance from branch collar to fracture point of branches from visually non-infested and $E A B$ infested green ash trees after static loading in northwest Ohio in 2009.

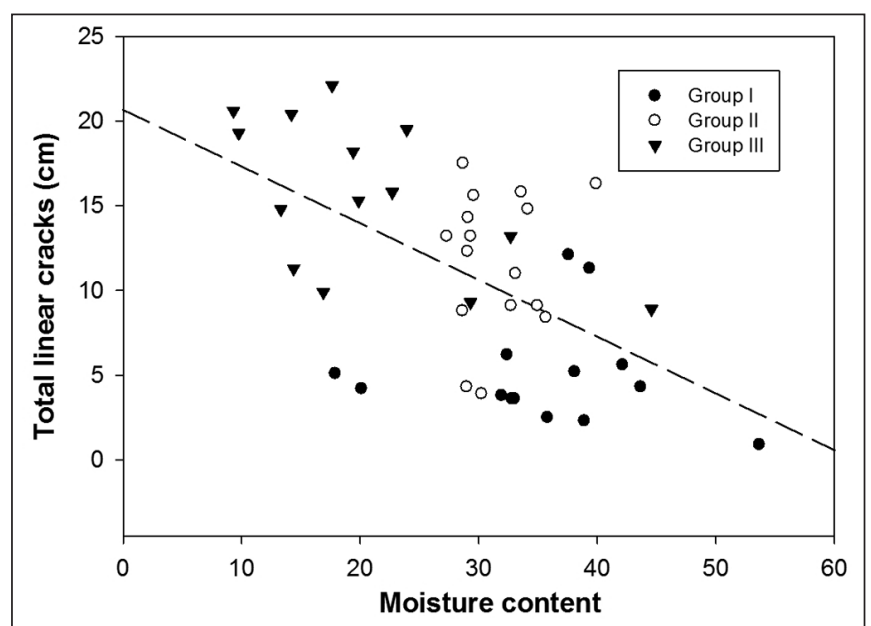

Figure 3. Relationship $\left(Y=-0.33+20.6 ; r^{2}=0.32\right)$ between total linear cracks $(\mathrm{cm})$ and moisture content in the zone of fracture of broken branches from visually un-infested and EAB infested green ash trees after static loading in northwest Ohio in 2009. 


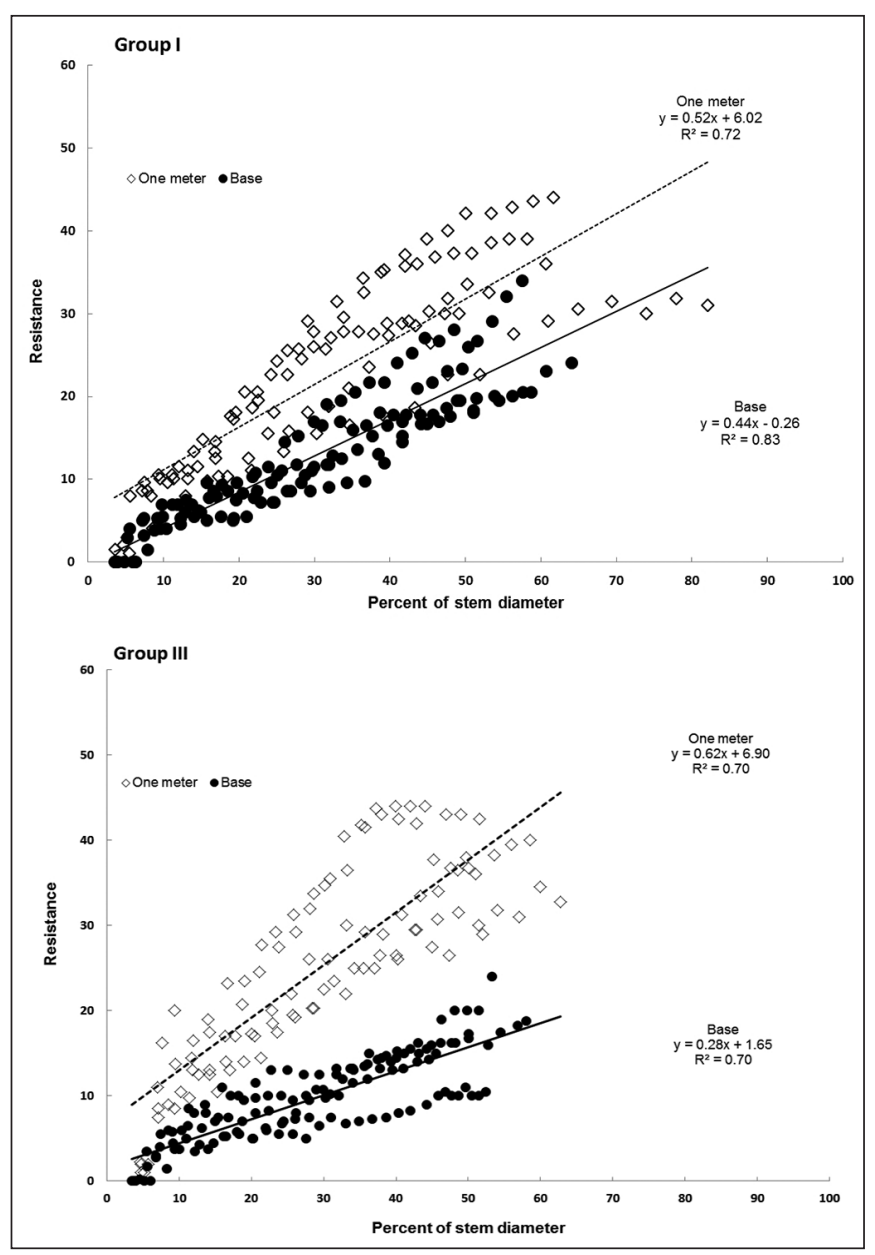

Figure 4. Drill resistance $(\mathrm{mm})$ measurements versus percentage stem diameter at drill points at the base and at $1 \mathrm{~m}$ above the base for visually un-infested and EAB infested ash trees in northwest Ohio in 2009.

and rigging activity will exert variable forces at single or multiple points on branches or basal stems of EAB infested ash trees. Detters et al. (2008) indicated that failure of the load bearing structure (branches and stems of trees) may occur during rigging and dismantling because of strength loss due to biotic effects. With advancing age of the EAB infestation, the risk concern of forces exerted by rigging and dismantling will exceed that emanating from the single load point responses we have observed in this study.

This work represents the first documented study that uses static loading and resistance drilling techniques to study the material degradation of tree wood caused by wood borers. Further work should be carried out on this EAB-ash tree complex as it pertains to tree structural and material integrity. This is especially relevant when large numbers of tree hosts occur in close proximity to each other or are prevalent species in community greenspaces.

Acknowledgements. The authors wish to express gratitude for the support from the city of Perrysburg, $\mathrm{OH}$; Joe Tommasi and the safety department of the Davey Tree Expert Co., Kent, OH; John Goodfellow of BioCompliance Consulting, Inc. Redmond, WA; and Andreas Detters of Brudi \& Partner TreeConsult, Germany.

\section{LITERATURE CITED}

Detters, A., C. Cowell, L. McKeown, and P. Howard. 2008. Evaluation of current rigging and dismantling practices used in arboriculture. Report submitted to the Health and Safety Executive and the Forestry Commission UK. 355 pp.

Ellison, M.J. 2005. Quantified tree risk assessment used in the management of amenity trees. Journal of Arboriculture 31(2):57- 65 .

Farrell, J.W. 2003. Structural features related to tree crotch strength. MSc Forestry. Thesis submitted to the Virginia Polytechnic Institute. $57 \mathrm{pp}$.

Goodfellow, J. 2009. Development of risk assessment criteria for branch failures within crowns of trees. Report to the Utility Arborist's Association, prepared by Biocompliance Consulting, Inc, Redmond, Washington, U.S. 78 pp.

Haack, R.A., E. Jendek, H-P Liu, K.R. Marchant, T.R. Petrice, T.M. Poland, and H. Ye. 2002. The emerald ash borer: A new exotic pest in North America. Newsletter of the Michigan Entomology Society 47:1-5.

Hauer, R., J.W. Wing, and J.O. Dawson. 1993. Ice storm damage to urban trees. Journal of Arboriculture 19(4):187-193.

Herms, D.A., A.K. Stone, and J.A. Chatfield. 2004. Emerald ash borer: The beginning of the end of ash in North America. Ohio State University Ash Alert. Accessed 06/01/20114. <http://ashalert.osu.edu/ beginning.asp $>$

James, K., and B. Kane. 2008. Precision digital instruments to measure dynamic wind loads on trees during storms. Agricultural and Forest Meteorology: 148(6-7):1055-1061.

Lilly, S., and T.D. Sydnor. 1995 Comparison of branch failure during static loading of silver and Norway maple. Journal of Arboriculture 21(6):302-305.

Niklas, K.J. 1997. Mechanical properties of black locust (Robinia pseudoacacia) wood: Correlations among elastic and rupture moduli, proportional limit and tissue density and specific gravity. Annals of Botany 79:479-485.

USDA: Forest Products Laboratory. 1987. Wood Handbook: Wood as an engineering material. Forest Service Agricultural Handbook. No 72. 433 pp.

Zobel, B.J., and J.P. van Buijtenen 1989. Wood variation: Its causes and control. New York: Springer-Verlag.

Anand B. Persad (corresponding author)

Entomologist

Davey Institute

1500 N. Mantua Street

Kent, Ohio 44240, U.S

abpersad@davey.com

John Siefer

Research Assistant

Davey Institute

1500 N. Mantua Street

Kent, Ohio 44240, U.S.

Roy Montan

Safety Dept. Davey Tree Experts

1500 N. Mantua Street

Kent, Ohio 44240, U.S.

Scott Kirby

District Manager

Davey Tree Experts, 409 Burbank Drive

Toledo, Ohio 43607, U.S. 
Oscar J. Rocha

Associate Professor

Department of Biological Sciences

Kent State University

Kent, Ohio 44242, U.S.

Michael E. Redding

Res. Entomtologist

USDA- ARS,

1680 Madison Ave.

Wooster, Ohio 44691, U.S.

Christopher M. Ranger

Res. Entomologist

USDA- ARS,

1680 Madison Ave.

Wooster, Ohio 44691, U.S.

Andrew W. Jones

Curator and Head of Ornithology

Cleveland Museum of Natural History,

1 Wade Oval Drive

Cleveland, Ohio 44106, U.S.

Résumé. L'agrile du frêne, un insecte épidémique chez les frênes, est couramment présent aux États-Unis et au Canada. Dans plusieurs régions, d'importantes populations de frênes sont affectées avec de nombreux arbres qui présentent des défoliations partielles à un état de dépérissement généralisé. De nombreux cas sont survenus, dans le NordOuest de l'Ohio aux États-Unis, où des branches et des tiges infestées par l'agrile du frêne sont tombées prématurément lors de travaux d'élagage de sécurité ou d'abattage. Cette étude a été initiée afin de résoudre la question des effets de l'agrile du frêne sur les propriétés structurales des branches et des tiges du frêne. Des frênes non infestés visuellement ainsi que d'autres avec des infestations récentes ou avancées ont été examinés. Les données provenant de test de charge statique sur les branches primaires ont indiqué que la résistance maximale à un stress de flexion jusqu'au point de rupture n'était significativement pas différente entre les arbres infestés par l'agrile du frêne de ceux non infestés. Cependant, l'examen des zones de fracture a révélé que le taux d'humidité du bois était significativement plus faible et le nombre de fissures plus élevé pour les sections de branches recueillies d'arbres infestés par l'agrile du frêne. Lors des tests de charge statique, les bris de branches au point d'attache survenaient seulement chez les arbres infestés par l'agrile du frêne. Lors d'une évaluation de la résistance du bois chez des frênes infestés et d'autres non infestés, une résistance significativement plus faible a été observée sur les tiges de frêne infestées à un stade avancé par l'agrile du frêne lorsque des trous étaient forés à la base des zones d'infestation comparativement à $1 \mathrm{~m}$ au-delà. Cette situation n'était pas observée lors de forage de trous à des hauteurs similaires au sein de frênes sans signes visuels d'infestation. Ces données pourraient aider à identifier les éléments de risques associés avec la dégradation structurale du bois chez les frênes, et ce aussi tôt que une à deux années après l'infestation par l'agrile du frêne.

Zusammenfassung. Der smaragtgrüne Eschenbohrer (EAB), eine invasive Bockkäferart auf Eschen, taucht gegenwärtig in den USA und Kanada auf. In vielen Regionen sind große Populationen von Eschen befallen und zeigen partielles bis vollständiges Absterben der Kronen. Im Nordwesten von Ohio, USA, existieren mehrere Fälle, wo infizierte Eschenäste bei der Totholzentnahme oder bei Fällungen ebenfalls versagten. Diese Studie wurde initiiert, um die Auswirkungen des Eschenbohrers auf die Materialeigenschaften von Ästen und Stämmen von Eschen zu klären. Sichtbar nicht-infizierte Eschenbäume und Bäume mit kürzlich auftretender und fortschreitender Infektion wurden untersucht. Die Daten aus Belastungstests an Ästen 1. Ordnung zeigen, dass die maximale Biegebelastung zum Zeitpunkt des Versagens nicht signifikant niedriger in infizierten Bäumen war als im Vergleich zu nichtinfizierten Bäumen. Eine Untersuchung der Abbruchstelle enthüllte, dass der Feuchtigkeitsgehalt des Holzes deutlich niedriger war und in den holzigen Abschnitten aus den Ästen der infizierten Bäume wurden mehr Risse beobachtet. Während der statischen Belastung tauchte ein Astversagen an der Verbindungsstelle nur bei den infizierten Bäumen auf. In einer Holzwiderstandbewertung von infiziertem und nicht-infiziertem Holz wurde ein signifikant niedrigerer Widerstand in hochgradig infizierten Eschenstämmen gemessen, die an der Basis angebohrt waren als im Vergleich bei Bäumen, die ca. einen Meter darüber angebohrt waren. Das konnte bei sichtbar nicht-infizierten Bäumen in gleicher Höhe nicht beobachtet werden. Diese Daten könnten bei der Identifizierung von Risikoelementen, die in Verbindung stehen mit strukturellem Materialabbau von Eschenholz bereits ein bis zwei Jahre nach der Infektion durch den Eschenbohrer helfen.

Resumen. El barrenador esmeralda del fresno (EAB, por sus siglas en inglés), un insecto invasivo de árboles de fresno, ocurre actualmente en los Estados Unidos y Canadá. En muchas regiones, grandes poblaciones de fresnos son afectados con muchos árboles presentando muerte regresiva de las copas parcial o totalmente. Existen varios casos en el noroeste de Ohio, U.S., donde ramas o tallos infestados por EAB fallan prematuramente durante la poda de madera seca o la remoción completa del árbol. Este estudio fue iniciado para resolver los efectos de EAB en las propiedades del material de ramas y tallos de fresno. Se examinaron visualmente árboles de fresno no infestados y otros con reciente y avanzada actividad de EAB. Los datos de cargas estáticas en ramas primarias indican que la máxima flexión a la falla no fue significativamente más baja en árboles infestados por EAB comparados con árboles no infestados. El examen de la zona de fractura, sin embargo, reveló que la madera húmeda fue significativamente más baja y más quebradiza, lo que se observó en secciones húmedas de las ramas tomadas de árboles infestados por EAB. Durante la carga estática, la falla de las ramas en la unión ocurrió solamente en los árboles infestados por EAB. En una evaluación de la resistencia de la madera de ramas infestados y no infestados cuando se taladraron en la base, comparados con sitios taladrados $1 \mathrm{~m}$ arriba. Estos datos pueden ayudar a identificar elementos de riesgo asociados con degradación estructural y material de madera de fresno en los primeros dos años después de la infestación por EAB. 